\title{
Selvmordsforebyggende strategi for England
}

Ved Lars M ehlum

Stadig flere land har de senere årene lansert nasjonale strategier for selumordsforebygging. På høstparten i 2002 ble den selumordsforebyggende strategien for England presentert for allmennheten. I denne artikkelen skal vi se noermere på hva denne strategien inneholder og huilke prinsipper den bygger på.

Det finnes mange ulike tilnærminger til og metoder for selvmordsforebygging, og disse bygger hovedsakelig på erfaringer fra de siste om lag 100 år. D et er imidlertid først i løpet av de siste 10-15 år at man har innsett nødvendigheten av å plassere enkeltstående tiltak innenfor en koordinert og strategisk sammenheng. $\mathrm{N}$ oe av bakgrunnen for dette er at omfanget av selvmordsproblemet i mange befolkningsgrupper har økt meget sterkt - dette har nødvendiggjort mer systematisk innsats. Samtidig har man innsett at det ikke eksisterer noe enkeltstående virkemiddel som kan forebygge alle selvmord, siden det er så mange og ulike faktorer som er involvert i årsakskjeden. Det er derfor behov for en sammenhengen de og hel hetlig strategi for selvmordsforebygging med samarbeid på tvers - mellom myndigheter, organisasjoner og enkeltpersoner. Det var dette Verdens helseorganisasjon ( W H O ) anbefal te sine medlemsland etter et viktig møte i Szeged i U ngarn i 1989. O g det er altså dette våre naboer i vest nå har gått inn for.

Selvmordsraten i England er ikke spesielt høy sammenliknet med de fleste land i Europa. Den har svingt mellom
$9 \operatorname{og} 10$ (/100 000) de siste 10 årene (tallet inkluderer unaturlige dødsfall med usikker årsak), mens den norske raten har ligget ca 50 \% høyere. På grunn av ulike systemer for fastsettelse av dødsårsaker i England og N orge er direkte sammenlikning av selvmordsratene vanskelig. Til tross for at ratene altså er relativt lave, registrerer man om lag 5000 selvmord pr år i England. M ens selvmordsraten har sunket blant eldre menn og kvinner de siste 20 år, har den steget blant unge menn. I gruppen av menn under 35 år er selvmord den vanligste dødsårsaken. Dette er noe av bakgrunnen for at det engelske hel sedepartementet har besl uttet å iverksette en langsiktig strategi for selvmordsforebygging. Etter lengre tids utviklingsarbeid ble den offentliggjort i september 2002 under det europeiske symposiet for selvmordsforskning i W arwick, i hjertet av England. Det var den engelske helseministeren, Jacqui Smith, personlig som presenterte strategien. U nder presentasjonen og den påfølgende diskusjonen viste hun seg som en både kunnskapsrik og engasjert politiker i forhold til dette feltet, og det lover meget godt.



1) inkl. dødsfall der det var usikkert om årsaken var ulykke eller selvmord.

Mange har

bidratt til den utviklingen

som ligger til grunn for den nye strategien. Det politiske grunnlaget ble lagt i regjeringsdokumentet "Saving Lives: 0 ur $\mathrm{H}$ ealthier $\mathrm{N}$ ation" (Department of $\mathrm{H}$ ealth 1999) og de mål settinger som ble trukket opp der. U t fra dette ble den nasjonale strategien formulert av en ekspertgruppe gjennom konsultasjoner med fagfolk i psykisk hel severn, forskere, brukere av tilbud og tjenester, representanter for frivillige organisasjoner og andre med relevant erfaring. Dette resulterte i et såkalt "C onsultation document" som ble utgitt i april 2002. En lang rekke instanser og enkel tpersoner fikk anledning til å gi kommentarer til dette dokumentet, og etter at viktige innspill var innarbeidet, var til slutt det endelige strategidokumentet klart for publisering.

\section{Styrende prinsipper}

Strategien baserer seg på fire grunnleggende prinsipper. For det første anser man at det er behov for en vidtfavnende involvering av mange sektorer i samfunnet. Selv om psykisk helsevern har et særlig ansvar for à forebygge selvmord, kan problemet ikke løses ved tiltak bare innen denne sektoren. Dette begrunnes med at det er vist at tre firedeler av dem som tar sitt liv i England, ikke er i kontakt med det psykiske helsevern. Det andre retningsgivende prinsippet for den engelske selvmordsforebyggingsstrategien er at den skal være evidensbasert. Der det er mulig, skal den ta utgangspunkt $\mathrm{i}$ kunnskap fra publisert forskning. $0 \mathrm{~g}$ der det nåværende evidensgrunnlaget er svakt, vil man søke å styrke det gjennom ny forskning. Et tredje prinsipp er at de selvmordsforebyggende tiltakene skal være spesifikke, praktisk gjennomførbare og tilgjengelige for monitorering*. Det siste prinsippet er at strategien også skal være gjenstand for kontinuerlig evaluering, og at den bør forandres når det viser seg nødvendig.

* M onitorering omfatter i denne sammenheng både fortløpende evaluering og resultatevaluering. 


\section{De enkelte målsettingene}

Strategien har som hovedmål å redusere forekomsten av selvmord og unaturlige dødsfall med ukjent årsak i England med minst en femdel innen 2010. For å nå fram til dette vil man arbeide ut fra seks målsettinger. I forhold til hver enkelt av disse har man anslått forebyggingspotensialet i forhold til sparte liv med utgangspunkt i hovedmålet (20\% reduksjon). $\mathrm{M}$ an har ikke satt opp disse anslagene som separate tallmessige mål, men de tjener til å synliggjøre hva som kan oppnås innenfor hvert av målområdene, og gir slik sett en tankevekker. Det er jo ellers lett å fortape seg i ratetall og endringer i ratenivå, og dermed glemme de mange enkeltpersoner som skjuler seg bak disse tallene.

\section{Målsettingene}

1) Redusere selvmordsrisikoen i viktige risikogrupper

2) Fremme psykisk helse i befolkningen

3) Redusere tilgangen til og dødeligheten av selvmordsmidler

4) Forbedre kvaliteten på massemedienes omtale av selvmord

5) Fremme forskning på selvmord og selvmordsforebygging

6) Bedre den epidemiologiske monitoreringen av selvmord for å kunne spore endringer i kjølvannet av selvmordsforebyggende tiltak

\section{1) Redusere selvmordsrisikoen i viktige risikogrupper}

Blant de mange mulige risikogrupper man her kunne vel ge å prioritere, har den engelske strategien brukt følgende kriterier for sitt utvalg: a) G ruppen skal ha en påvist statistisk økt risiko for selvmord, b) selvmordforekomsten i gruppen skal være kjent, c) det finnes evidensgrunnlag å basere forebyggende tiltak på og d) det er mulig å monitorere effekten av iverksatte forebyggen de tiltak. Flere potensielle risikogrupper har falt ut av strategien på grunn av at de ikke tilfredsstiller ett eller flere av disse kriteriene. I slike tilfeller er det en målsetting i stedet å øke kunnskapsgrunnlaget slik at det senere kan avklares om det virkelig bør satses ressurser på forebygging overfor disse gruppene.

Det første delmålet i denne første målsettingen er å redusere antall selvmord blant personer som er eller nylig (i løpet av siste år) har vært i behandling innen det psykiske helsevern. I planen vises det til viktige tiltak som er under iverksetting, slik som styrking av desentral iserte akuttpsykiatriske tjenester, utarbeidelse av skriftlige behandlingsplaner for hver enkelt pasient, opplæring av alle medarbeidere ved akuttpsykiatriske avdelinger i vurdering og håndtering av selvmordsrisiko og fysisk sikring av alle sengeavdelinger med fjerning eller endring av inventar som kan benyttes til selvmord (gardinoppheng etc.). I tillegg er flere nye tiltak besluttet iverksatt slik at man til sammen går inn for "Twelve points to a safer service", som skal gjennomføres i årene som kommer. Disse tiltakene er utviklet i kjølvannet av det store forskningsprosjektet "N ational C onfidential Inquiry" (A ppleby et al. 2001), som baserer seg på informasjon om et høyt antall personer som hadde gjort sel vmord under eller etter psykiatrisk behandling. A nbefalingene som ligger i disse tolv punktene, harmonerer godt med hva man har kommet fram til også i andre land. Som helhet handler disse tiltakene om å gi tidlig og effektiv hjelp til selvmordsnære personer med psykisk lidelse, sikre en god nok beskyttelse under behandling og sikre kontinuitet i behandlingen etter utskrivning.

Det andre delmålet i denne delen av strategien er å redusere antall senere selvmord blant personer som har gjort selvmordsforsøk. Her har man planlagt å styrke kvaliteten på den innsatsen som gjøres ved akuttjen ester på sykehus og legevaktsmottak, blant annet gjennom opplæring. De øvrige delmålene fokuserer på å redusere antall selvmord blant unge menn gjennom forebygging av rusmisbruk og gjennom å øke tilbudet om krisestøtte for unge menn som er under utdanning. V idere har man besluttet å fokusere spesifikt på innsatte i fengsler, blant annet gjen- nom å styrke hel setjenesten for fanger og gjennom å utvikle et samarbeid med frivillige hjelpere som kan gi sosial støtte og hjelp gjennom samtale. Endelig vil man iverksette enkel te tiltak for å redusere antall selvmord blant gårdbrukere.

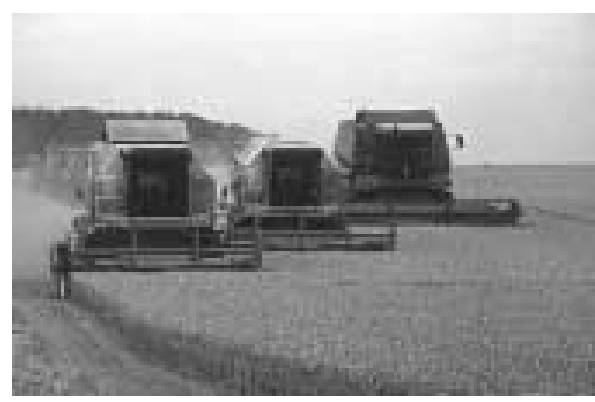

2) F remme psykisk helse i befolkningen

$M$ an har her tatt utgangspunkt i antakelsen om at selvmordsraten reflekterer den mentale helse i befolkningen. Derfor har man besluttet å fremme befolkningens psykiske helse gjennom en rekke tiltak rettet mot:

- Sosialt underprivilegerte og ekskluderte grupper

- Etniske minoriteter

- Rusmisbrukere

- O fre for vold og seksuelt misbruk

- Barn og unge under 18 år

- Kvinner under og etter svangerskap

- Eldre

- Etterlatte ved selvmord

D et nasjonal e strategi dokumentet knytter relativt få konkrete forebyggingstiltak til hver av disse gruppene, og det gjenstår å se om man vil makte å opprettholde et spesifikt fokus på alle disse områdene på en gang.

3) Redusere tilgangen til og dødeligheten av selvmordsmidler

I England har man tidligere vist tydelig at det er mulig å redusere selvmordsraten i befolkningen ved å redusere til gangen til og dødeligheten av selvmordsmidler. Best kjent er reduksjonen i antall forgiftningsselvmord etter avgiftning av husholdningsgassen (Kreitman 1976). Den mest brukte selvmordsmetoden i England er i dag hengning, og det er vanskelig å se for seg hvordan man kan endre tilgangen til denne metoden i befolkningen i 


\section{Selvmord ${ }^{1)}$ etter metode og kjønn. England 2000}
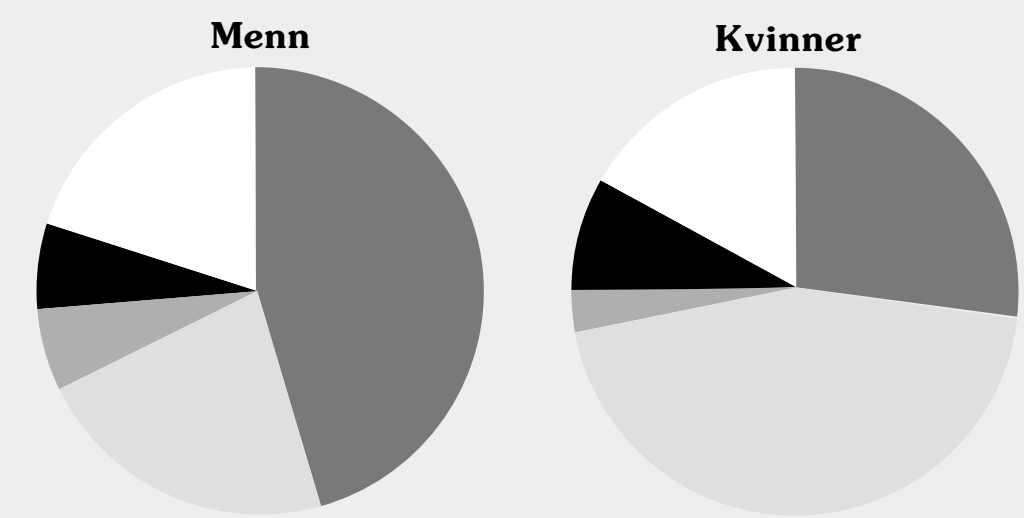

Henging Forgiftning Eksos
A ndre metoder

1) inkl. dødsfall der det var usikkert om årsaken var ulykke eller selvmord.

sin alminnelighet. I psykiatriske avdelinger og i fengsler er det derimot mulig, og man har besluttet å arbeide systematisk for å minske tilgangen på denne selvmordsmetoden innenfor disse sammenhengene (se ovenfor). $N$ år det gjelder forgiftningsselvmord, har man allerede gjort positive erfaringer med å redusere pakningsstørrelsen for over-disk-salg av paracetamolpreparater (H awton et al. 2001). H er vil man gå ett skritt videre og fremme sikrere forskrivning også av andre medikamenter som typisk benyttes i suicidal hensikt.

Samtidig vil man undersøke om det bør etableres bedre rutiner for kassering av ubrukte eller overflødige medikamenter fra private husholdninger. $M$ an vurderer også å gi informasjon til allmennheten om farene ved overdose med paracetamolpreparater. De fleste selvmordsnære personer ville neppe valgt paracetamol som forgiftningsmetode dersom de hadde kjent bedre til virkningene av overdose med denne typen medikament.

I strategidokumentet introduseres det en rekke praktiske forslag til tiltak av blant annet teknisk, juridisk, og informasjonsmessig art, som alle har til hensikt å begrense selvmordsnære personers umiddelbaretilgang til spesifikke sel vmordsmidler. $\mathrm{H}$ er er det mange mulige veier å gå, men dersom man skal lykkes vil det trolig være nødvendig å fokusere innsatsen noe. Dersom man eksempelvis skal få bilprodusenter til å endre sine produkter (f.eks. endre formen på eksosrør, eller montere eksosfølere i bilens kupé slik at motoren stoppes når eksosnivået blir for høyt), må man nok øve et visst press og trolig bruke både "pisk" og "gulrot". Det samme gjelder endring av brokonstruksjoner eller sikringstiltak for høye bygninger.

I England er man i den heldige situasjon at det er meget få selvmord ved skyting; slike selvmord utgjør bare om lag $2 \%$ av alle selvmord. Derfor har man heller ikke vedtatt noen spesifikke tiltak for å forebygge skyteselvmord. D ette må forstås på bakgrunn av at det bare er om lag $5 \%$ av alle husholdninger i England som har skytevåpen. I N orge er situasjonen dramatisk annerledes både når det gjel der publikums tilgang til skytevåpen og forekomst av selvmord ved skyting.

4) Forbedre kvaliteten på massemedienes omtale av selvmord

Den frivillige krisehjel porganisasjonen "T he Samaritans" er blant dem som har arbeidet aktivt for å gi informasjon til journalister og andre fagfolk i England om hvordan man kan håndtere selvmord som tema i massemediene uten at det fører til smitteeffekter. Et viktig poeng er å anerkjenne medienes konstruktive rolle i å gjøre publikum oppmerksom på problemene og hvordan man kan bidra til å løse dem - ikke minst gjennom å benytte etablerte hjel petjenester. $\mathrm{H}$ er handler det også om å redusere stigmaet ved selv- mordsatferd og ved psykisk lidelse generelt. Den engelske strategien for selvmordsforebygging vil videreføre og intensivere arbeidet opp mot massemediene.

5) F remme forskning på selvmord og selvmordsforebygging

I løpet av de senere år har noe av den beste selvmordsforskningen i et internasjonalt perspektiv kommet fra England. $M$ an har bygget opp sterke forskergrupper på området, og disse har bidratt til å fremskaffe mye av evidensgrunnlaget for den aktuelle strategien for selvmordsforebygging. $M$ an innser imidlertid at det fortsatt er mange uavklarte spørsmål og derfor mange uløste oppgaver for forskere. I den foreliggende strategien legges det opp til å koordinere forskningsinnsatsen noe bedre enn hittil, og ansvaret for denne koordineringen er blitt lagt til $C$ entre for Suicide Research ved U niversitetet i 0 xford under Keith $\mathrm{H}$ awtons ledel se. Ved siden av å gi glimrende forskningsmessige bidrag har dette senteret også produsert viktige og systematiske oversi kter over eksisterende forskning og kunnskapsstatus. Det legges opp til at arbeidet med slike oversikter skal videreføres og resul tatene gjøres kjent for brede grupper innen det selvmordsforebyggen de arbeidet.

6) B edre den epidemiologiske monitoreringen av selvmord for å kunne spore endringer i kjølvannet av selvmordsforebyggende tiltak

Ekspertgruppen som står bak det nasjonale strategidokumentet, har innsett betydningen av å følge den videre epidemiologiske utviklingen av selvmordsproblemet i ulike deler av befolkningen i årene fremover. M ed utgangspunkt i slike data vil man kunne evaluere den nasjonale strategien og dens ulike satsninger samtidig som det er mulig å avdekke nye og uheldige utviklingstrekk. Det later til at man har fătt etablert en del registre og monitoreringssystemer til dette formålet, og det vil bli innhentet epidemiologiske data fra flere nye kilder.

\section{Har vi noe å laere av denne strategien?}

På de britiske øyer har man av en eller annen grunn valgt å etablere separate nasjonale strategier for de ulike deler av 


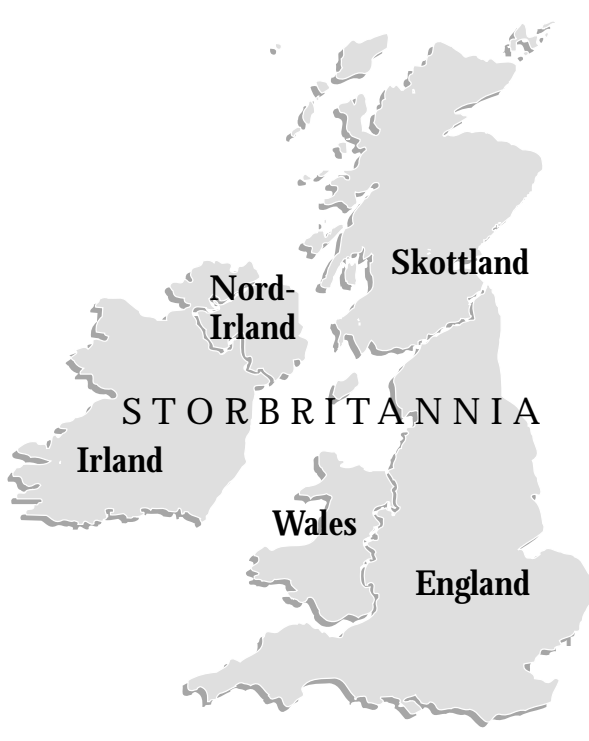

det forente kongedømme. Således var ikke Skottland så mye senere ute med sin strategi enn England. Likevel vil det nok bli den foreliggende engelske strategien fagmiljøer over hele verden nå kommer til å rette oppmerksomheten mot. Blant de store landene i verden er det hittil bare England som har laget noe i nærheten av en samlet og helhetlig strategi med en målstruktur for praktisk gjennomførbare tiltak.

Ett av særtrekkene ved denne strategien er at den er nøye med å forankre ansvaret for de ulike tiltakene til definerte ledd. Og ansvaret for den helhetlige implementeringen og overvåkningen av strategien er tillagt det nyetablerte $\mathrm{N}$ ational Institute for M ental H ealth i Leeds. Strategidokumentet er meget enkelt og oversiktlig, men man ser fort at det er nedlagt mye arbeid i gjennomtenkte prinsipper og prioriteringer. Det hadde nok vært fristende - og ikke minst mer politisk korrekt - å inkludere enda flere målsettinger. M en man har klart å holde seg til de bærende prinsippene, blant annet at tiltakene skal være fokuserte, praktisk gjennomførbare og basert på empirisk evidens. N å kan man innvende at det ikke er så lett å demonstrere forskningsmessig stringent effekten av alle de forebyggende tiltak som vi faktisk har tro på at virker. Derfor må vi ikke bruke slike kriterier blindt når vi skal velge våre forebyggingsstrategier.

Strategidokumentet legger forholdsvis mye vekt på forebygging av selvmord gjennom mer effektiv bruk av psykisk helsevern og gjennom bedring av standarden i behandlingstilbudet som ytes til mennessker med psykisk lidelse. Her er det, som vi har sett, et stort forbedringspotensial samtidig som det er tilgang på en rekke konkrete og gjennomførbare tiltak. Situa- sjonen i N orge skiller seg ikke vesentlig fra den man har i England på en rekke av de punktene som er nevnt, så her har vi de samme utfordringene å stri med.

I $\mathrm{N}$ orge har vi riktignok arbei det lenge med å få etablert kontinuerlige behandlingskjeder for pasienter som skrives ut fra sykehus etter selvmordsforsøk. Trolig er vi kommet betydelig lenger på det feltet enn i England. M en fortsatt er mangel på kontinuitet i behandlingen et problem for mange som benytter tjenester i det psykiske helsevern også i N orge.

Den engelske strategien har naturlig nok forebygging av selvmord som målsetting. M en en slik strategi burde, etter denne forfatters syn, også delvis ha som mål å redusere antall selvmordsforsøk, ikke bare fordi disse ofte er forstadier på veien mot gjennomført selvmord, men også fordi de representerer et problem i seg selv. Suicidalkriser er uttrykk for store psykiske og eksistensielle problemer hos den det gjelder, og vil som regel medføre betydelig redusert livskvalitet over tid, både for den suicidale og hans eller hennes nærmeste. Til tross for gjennomgåen de god kvalitet og omfang finnes det områder som ikke er særlig godt dekket av den engel ske strategien. Vi savner blant annet en bredere tilnærming til arbeidsplassrelaterte risikofaktorer. M ilitært personell er overhodet ikke nevnt til tross for alarmerende meldinger om økende selvmordstall blant enkelte grupper av veteraner i England. Seksuelle minoriteter omfattes ikke av den engel ske strategien for sel vmordsforebygging til tross for at det finnes evidens for at homofile/lesbiske har en økt risiko for å gjøre selvmordsforsøk. Dette er bare noen eksempler på risikogrupper som i alle fall burde ha vært nevnt.

Det ville ikke vært unaturlig om ekspertene som har utarbeidet den engel ske strategien, delvis hadde bygget på erfaringer man har gjort seg med tilsvarende strategier i andre land. Det ser imidlertid ut til at man i liten eller ingen grad har benyttet seg av slike erfaringer. I stedet har man benyttet sine mange eksperter og fagmiljøer - og rett skal være rett - resultatet er blitt svært bra. H vordan tenker man seg så den videre utviklingen? Engelskmennene kaller dette en "evolving strategy". D et betyr at strategien skal være langsiktig og forventes å utvikle seg og bli revidert årlig i takt med framskritt som gjøres på fel tet og med framvoksende evidensgrunnlag. Det er et meget klokt, men også krevende, trekk. Det blir spennende å følge med i utviklingen i England de nærmeste årene.

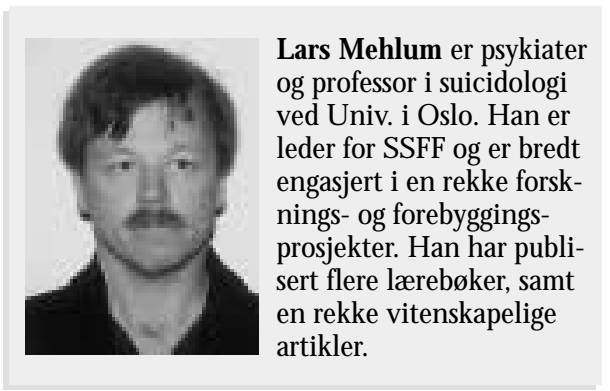

\section{Referanser}

A ppleby L, Shaw J, Sherrat J et al. Safety first: $\mathrm{N}$ ational $\mathbf{C}$ onfidential Inquiry into Suicide and H omicide by People with Mental IIIness. London, Department of $\mathrm{H}$ ealth, 2001.

Department of $\mathrm{H}$ ealth. Saving Lives: $\mathbf{O}$ ur $\mathrm{H}$ ealthier $\mathrm{N}$ ation. London: Department of $\mathrm{H}$ ealth, 1999.

Department of $\mathrm{H}$ ealth: $\mathbf{N}$ ational Suicide Prevention Strategy for England. London: Department of $H$ ealth, 2002.

H awton K, Townsend E, D eeks J et al. E ffects of pack legislation restricting pack sizes of paracetamol and salicylates on self-poisoning in the U nited Kingdom: before and after study. British M edical Journal 2001; 19: 1203-7.

Kreitman N . T he coal gas story: U nited Kingdom suicide rates, 1960-1971. British Journal of Preventative and Social M edicine 1976; 30: 86-93.

\section{Internett-ressurser}

$\mathrm{N}$ ational Institute for $\mathrm{M}$ ental $\mathrm{H}$ ealth for England: Suicide Prevention Programme:

www.nimhe.org.uk/priorities/suicide.asp

Department of $\mathrm{H}$ ealth: $\mathrm{N}$ ational Suicide Prevention Strategy for England, 2002

- Consultation document:

\section{WWW.doh.gov.uk/mentalhealth/} suicideprevention.pdf

- A bout the strategy

\section{WWw.doh.gov.uk/mentalhealth/} suicideprevention.htm

Safety first: $\mathrm{N}$ ational C onfidential Inquiry into Suicide and $\mathrm{H}$ omicide by People with $\mathrm{M}$ ental IIIness. London, Department of $\mathrm{H}$ ealth, 2001.

\section{Www.doh.gov.uk/mentalhealth/safetyfirst/} safetyfirst.pdf

(Se også "N asjonale strategier..."', s. 21.) 